Article

\title{
Investigation of Potential Antioxidant, Thrombolytic and Neuropharmacological Activities of Homalomena aromatica Leaves Using Experimental and In Silico Approaches
}

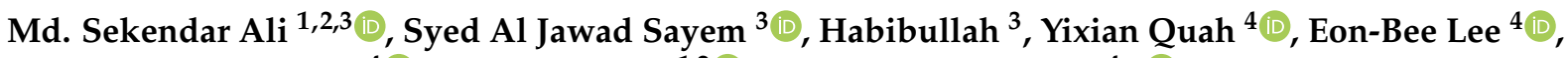 \\ Biruk Tesfaye Birhanu ${ }^{4}(\mathbb{D})$, Kyoungho Suk ${ }^{1,2}$ and Seung-Chun Park ${ }^{4, *}$ (D) \\ 1 Department of Biomedical Science, School of Medicine, Brain Science and Engineering Institute, Kyungpook \\ National University, Daegu 41944, Korea; alipharm2000@gmail.com (M.S.A.); ksuk@knu.ac.kr (K.S.) \\ 2 Department of Pharmacology, School of Medicine, Brain Science and Engineering Institute, Kyungpook \\ National University, Daegu 41944, Korea \\ 3 Department of Pharmacy, International Islamic University Chittagong, Kumira, Chittagong 4318, Bangladesh; \\ aljawadsayem@gmail.com (S.A.J.S.); habibmahirbd@gmail.com (H.) \\ 4 Laboratory of Veterinary Pharmacokinetics and Pharmacodynamics, College of Veterinary Medicine, \\ Kyungpook National University, Daegu 41566, Korea; im.yixianquah@gmail.com (Y.Q.); \\ eonbee@gmail.com (E.-B.L.); btbtes@gmail.com (B.T.B.) \\ * Correspondence: parksch@knu.ac.kr; Tel.: +82-53-950-19-5964
}

Citation: Ali, M.S.; Sayem, S.A.J.; Habibullah; Quah, Y.; Lee, E.-B.; Birhanu, B.T.; Suk, K.; Park, S.-C. Investigation of Potential Antioxidant, Thrombolytic and Neuropharmacological Activities of Homalomena aromatica Leaves Using Experimental and In Silico Approaches. Molecules 2021, 26, 975. https://doi.org/10.3390/ molecules 26040975

Academic Editors: Francesco Cacciola and Md. Moshfekus Saleh-E-In Received: 15 January 2021

Accepted: 9 February 2021

Published: 12 February 2021

Publisher's Note: MDPI stays neutral with regard to jurisdictional claims in published maps and institutional affiliations.

Copyright: (c) 2021 by the authors. Licensee MDPI, Basel, Switzerland. This article is an open access article distributed under the terms and conditions of the Creative Commons Attribution (CC BY) license (https:/ / creativecommons.org/licenses/by/ $4.0 /)$.

\begin{abstract}
The leaves of Homalomena aromatica are traditionally used in Bangladesh for the treatment of different chronic ailments. The purpose of this study was to explore in vitro antioxidant, thrombolytic activities, and in vivo neuropharmacological effects of methanolic extract of Homalomena aromatica (MEHA) leaves. Antioxidant activity of MEHA was assessed by a DPPH free radical scavenging assay and total phenolics content, total flavonoids content were also measured. The thrombolytic activity was determined by percentage of clot lysis and neuropharmacological activities by hole board, tail suspension, forced swimming and elevated plus maze tests. The results showed that the $\mathrm{IC}_{50}$ value of the extract against DPPH was $199.51 \mu \mathrm{g} / \mathrm{mL}$. Quantitative analysis displayed higher contents of phenolics and flavonoids (147.71 mg gallic acid equivalent/g \& $66.65 \mathrm{mg}$ quercetin equivalent/g dried extract, respectively). The extract also showed a significant clot lysis (33.31\%) activity. In case of anxiolytic activity, the elevate plus maze (EPM) test demonstrated an increase in time spent in open arms, and in case of hole board test, the number of head dipping was also significantly increased $(p<0.05)$. All the test compared with control (1\% Tween in water) and standard (diazepam $1 \mathrm{mg} / \mathrm{kg})$, significant dose $(200 \& 400 \mathrm{mg} / \mathrm{kg})$ dependent anxiolytic activity was found. In antidepressant activity, there was a significant decrease in period of immobility in both test models (tail suspension and forced swimming) $(p<0.05)$. Moreover, 13 compounds were identified as bioactive, showed good binding affinities to xanthine oxidoreductase, tissue plasminogen activator receptor, potassium channel receptor, human serotonin receptor targets in molecular docking experiments. Furthermore, ADME/T analysis revealed their drug-likeness, likely pharmacological actions and non-toxic upon consumption. Taken together, our finding support the traditional medicinal use of this plant, which may provide a potential source for future drug discovery.
\end{abstract}

Keywords: H. aromatica; antioxidant; thrombolytic; anxiolytic; antidepressant; essential oil; molecular docking; ADME profiling

\section{Introduction}

Thrombosis is a blood clotting disorder and one of the leading causes of death in developed countries [1]. Besides modern treatment strategies, traditional and herbal drugs could be the potential alternatives to treat thrombosis for their safety profiles.

Neuropsychiatric disorders such as depression are a common but serious mood illness resulting in severe symptoms such as sadness, feelings of guilt, loss of interest affecting 
sleeping, eating and other daily activities. If untreated, depression along with anxiety may aggravate the symptoms, worsen the complications, and ultimately lead to suicidal ideation risks [2]. The real etiology of depression and anxiety are still not clearly known, however they may arise due to disruption of the antioxidant defence system which eventually causes redox imbalance or oxidative stress [3]. The excessive production of oxidative reactive species (ROS) in the brain creates a cellular discrepancy condition that causes cognitive deteriorations and neurological mechanism damage [4]. Antioxidant therapies may be used to ameliorate the progressive tissue damage, preventing imbalance of ROS production in the nervous system. The beneficial effects in mild depressive conditions of using currently available antidepressants is still in doubt and moreover, they also produce many unwanted side effects [5]. On the other hand, taking only antioxidants may not produce the expected therapeutic effect. Therefore, pharmacotherapy for a longer period of time, for example co-administration of antioxidants along with psychiatric agents is suggested to treat such critical health diseases. In this circumstance, the investigation of possible bioactive leads from medicinal plants covering multiple pharmacological targets is a main aim of worldwide research, because medicinal plants some of the most abundant sources of pharmacological active compounds for the development of a new drugs. Nowadays, in vitro and in vivo model in silico methods are also widely used to scrutinize the biological activities of phytochemicals with better safety, economic and drug-likeliness properties [6].

Homalomena aromatica (Spreng.) Schott is a perennial medicinal herb belonging to the Araceae family that occurs in the Chittagong hills region in Bangladesh. It has many traditional usages, for instances, management of coughs, colds, stomach problems, skin diseases and jaundice [7]. It is also used by the tribal habitants in the hilly areas of the eastern regions of India (Sikkim, Arunachal) and Bhutan as an anti-inflammatory, antidepressant, analgesic, sedative, antispasmodic, antiseptic and pain killing agent [7]. There are a lot of scientific studies which have showed that $H$. aromatica has diverse pharmacological activities like antibacterial [8], ulcer protective [9] and hepatoprotective effects [10]. GC-MS analysis has revealed that specific compounds are present in $H$. aromatica leaves, most of them in the form of essential oils [11]. Besides essential oils, it also contains alkaloids, saponins, cardioactive glycosides, polyphenolics, fixed oils, oleic acid, undecylenic acid, epiandrosterone, palmitic acid and linoleic acid [12]. Among them, we have selected 13 compounds for in silico studies to verify their target receptor binding affinity to prove the basis of their potential antioxidant, thrombolytic, antidepressant and anxiolytic activities. Previous studies have shown the best activity of certain compounds of this plant such as T-cadinol, which is an antioxidant and thrombolytic compound [13], 4-terpineol that has anxiolytic activity [14], and $\alpha$-cadinene that exerts antidepressant effects [15].

Nonetheless, while plant has many traditional usages, as yet, according to our knowledge, there are no exclusive scientific investigations which have been carried out to search for antioxidant, thrombolytic and neuropharmacological activities of this plant along using in silico approaches. Therefore, our current study has been designed to systematically explore the antioxidant, thrombolytic, antidepressant and anxiolytic activities along with in silico methods to reveal the potential target insights of the documented bioactive compounds for potentially finding lead constituents from H. aromatica leaves.

\section{Results and Discussion}

Historically plants are the major source of invaluable therapeutic agents for the treatment of different diseases [16]. Natural products generate a wide range of interest to discover new drugs, even in this modern age, because plants are magnificent sources of biomolecules providing new pathways to treat many chronic ailments [17]. Nowadays, available drugs on the market for the treatment of thrombosis include antiplatelet agents (aspirin, thienopyridine) and anticoagulants (heparin, warfarin, hirudin, human activated protein C) that act by preventing blood clotting. There are also a number of clinically available antidepressant and anxiolytic drugs, apparently acting via different mechanisms, including dopaminergic, noradrenergic or serotonergic pathways. However, these drugs 
have limitations including insufficient efficacy over a longer period of time and unexpected side effects [18]. Therefore, in recent years many researchers have explored alternative source of drugs that seemingly show less or no side effects. Many natural herbal plants, for example, Chaenomeles sinensis, Spatholobus suberectus, Salvia miltiorrhiza, Garcinia nervosa, Piper longum, Agrimonia pilosa, Licania pittieri have been investigated for thrombolytic effects [19]; and Crocus sativus, Passiflora incarnata, Piper methysticum have been tested for their anxiolytic and antidepressant activities [20,21]. The presence of antioxidants, alkaloids and many other phenolic and flavonoid compounds are reported to have anti-nociceptive, anti-inflammatory, antimicrobial, anticancer and thrombolytic activities [22].

In order to develop herbal drugs for thrombosis, anxiety and depression the use of animal models are inevitable. Therefore, validated experimental protocols using experimental animals are a relevant contributor for preclinical and clinical inference. In this study, we have used in vitro and in vivo along with in silico approaches to investigate the possible antioxidant, antidepressant, anxiolytic and thrombolytic activities of MEHA.

\subsection{In Vitro Antioxidant Activity \\ DPPH Free Radical Scavenging Assay}

Imbalances between the production of ROS and intracellular antioxidants provoke the formation of excessive reactive species leading to the process of atherothrombosis via release of pro-thrombotic and inflammatory molecules [23,24]. Similarly, excessive production of ROS and meager antioxidant defenses in the brain make it highly vulnerable to the pathophysiology of different diseases. Evidence suggests that oxidative stress is connected to anxiety-related behavior by destabilizing neurotransmission and brain activities [25]. An oxidant can prevent or delay the oxidation of a substrate by hydrogen transfer, single oxygen transfer, chelating peroxidase metals, inactivating lipoxygenase and thus can prevent any abnormal harms into the cells [26]. Results for the DPPH free radical scavenging activity of MEHA are shown in Figure 1 . The extract showed an efficient scavenging effect in the DPPH assay. The half inhibition concentration $\left(\mathrm{IC}_{50}\right)$ for free radicals achieved by MEHA is $199.51 \mu \mathrm{g} / \mathrm{mL}$ which is statistically significant compared to that $\left(\mathrm{IC}_{50}=42.70 \mu \mathrm{g} / \mathrm{mL}\right)$ of ascorbic acid (reference compound).

A

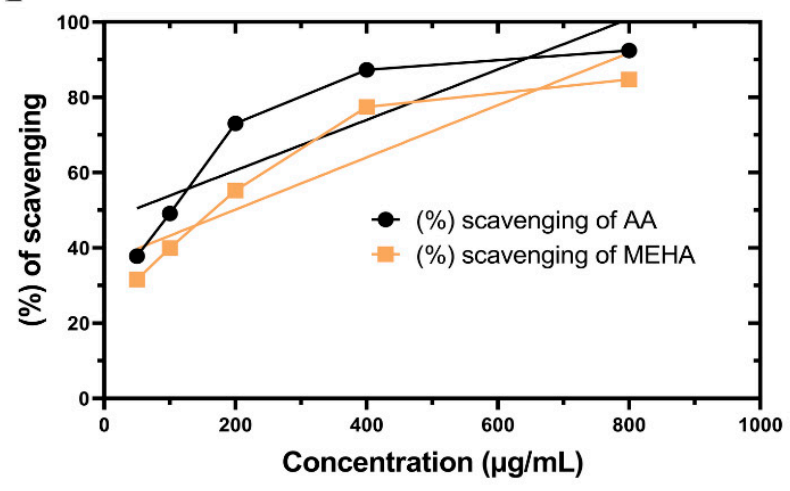

B

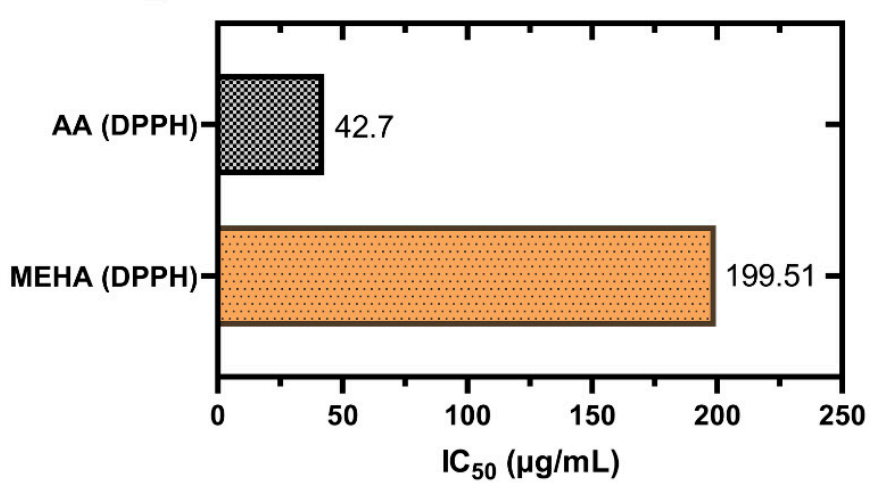

Figure 1. DPPH free radical scavenging activity of MEHA compared with the reference standard ascorbic acid (AA). (A) Percentage of DPPH free radical scavenging activity by different concentrations of the MEHA and reference standard AA. (B) $\mathrm{IC}_{50}$ values for DPPH free radical scavenging activity of MEHA and AA. Values are expressed as mean \pm SEM of three independent experiments. MEHA refers to methanol extract of Homalomena aromatica leaves. DPPH: 1,1-diphenyl-2picrylhydrazyl radical. 
The result proves that the antioxidant capability of MEHA can be regarded as a potential antioxidant remedy for thrombosis, anxiety and depression. Regular supplementation of antioxidants may provide the desired outcome due to the presence of polyphenols providing natural defenses against these diseases.

\subsection{Total Phenolics and Flavonoids Content}

Polyphenols are plant secondary metabolites that provide potential health benefits by dietary intake acting as potential antioxidants [27], which may boost the brain energy by scavenging ROS and inhibit the inflammation signaling system ameliorating depression and anxiety [28]. Flavonoids are compounds which can reduce neuroinflammation, potentiate the $\mathrm{GABA}_{\mathrm{A}}-\mathrm{Cl}^{-}$channel complex, modulate the monoaminergic neurotransmitter and increase dopamine, serotonin, and monoamines levels in the central nervous system [29]. Polyphenols have also gained researchers' attention as potential therapeutic agents which act by combating oxidative stress to protect from cardiovascular diseases [30]. These compounds prevent the development of atherosclerosis and protect the endothelium and reduce the oxidation of LDL and cholesterol [31]. We have analyzed and measured the amount of polyphenols (Table 1) measured as total phenolics content $(147.716 \pm 5.07 \mathrm{mg} \mathrm{GAE} / \mathrm{g})$ and total flavonoids content $(66.65 \pm 6.208 \mathrm{mg} \mathrm{QE} / \mathrm{g}$ dried extract). These results provide the information that MEHA could be the potential therapeutic target for the treatment of neuropsychiatric disorders and thrombosis.

Table 1. Total phenolics and flavonoids content of MEHA.

\begin{tabular}{ccc}
\hline Sample & Total Phenolics Content (mg GAE/g Extract) & Total Flavonoids Content (mg QE/g Extract) \\
\hline MEHA & $147.716 \pm 5.07$ & $66.65 \pm 6.208$ \\
\hline
\end{tabular}

Each value is represented as mean \pm SEM of three independent experiments. GAE, gallic acid equivalent; $Q E$, quercetin equivalent.

\subsection{Thrombolytic Activity}

Formation of blood clots is one of the chief causes of blood circulation problems. Thrombi or emboli can be deposited in the blood vessels and can obstruct blood flow in that location depriving tissues from normal blood flow and oxygen. Ultimately, this can result in damage, destruction or even death of the tissues in that area. Thrombolysis is the process by which blood clots can be destroyed by administering thrombolytic drugs including recombinant tissue plasminogen activator, which reinforce the normal destruction of blood clots by the body's enzymes, however, this may cause an increased risk of bleeding so it is usually used only for specific situations (such as massive pulmonary embolism and severe strokes). Plants are natural sources of many remedies including ones for the treatment of thrombosis. There are many research works that have reported the discovery of plants with thrombolytic activity and the use of such plants as a source of medicines that may lead to the prevention and treatment of strokes and coronary disease [32,33]. It has been demonstrated that phenolics and flavonoids obtained from plant sources might have significant thrombolytic activity potential [34]. The in vitro thrombolytic activity assays revealed that HEMA showed 33.31\% clot lysis effect $(p<0.001)$ which was significant compared to negative control $(4.84 \%)$, whereas the standard streptokinase used as positive control showed 75\% clot lysis (Figure 2). 
A

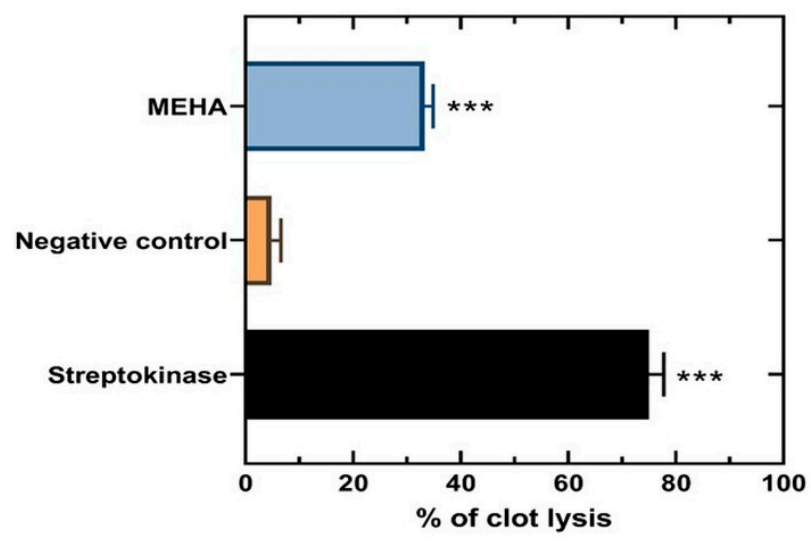

B

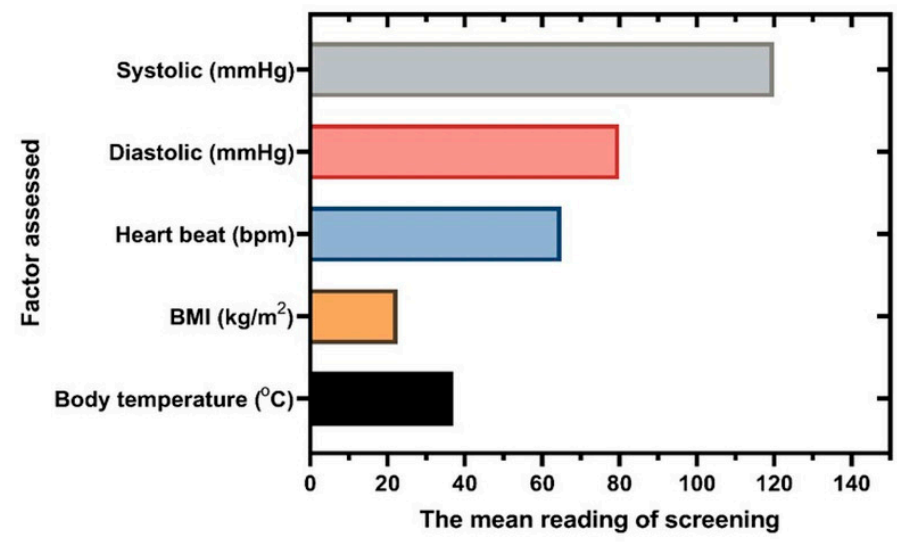

Figure 2. (A) The clot lysis activity of MEHA, streptokinase (SK) and distilled water (negative control). (B) The healthy volunteer status presented. Results are expressed as mean \pm SEM of three independent experiments. ${ }^{* * *} p<0.001$, significantly different from control; ANOVA followed by Dunnett's test. MEHA: Methanol extract of Homalomena aromatica leaves.

\subsection{Anxiolytic Activity}

Amongst many significant animal experiments, elevated plus maze (EPM) is one of the most important behavioral assays for the assessment of anxiolytic-like effects. The sensitivity of this test to the effect of anti-anxiety and anxiogenic drugs acting to the GABA benzodiazepine complex is very high [35]. The EPM apparatus has two opposite open and two closed arms, where regular mice normally spend much of their allowed time in the closed arms. This type of behavior reflects a distaste for open arms created by the anxiety caused by open spaces. Drug-like anxiolytics that enhance the exploration of open arms are believed to have anxiolytic activity. Administration of extract significantly increased the time spent in open arms compared to the control (Figure 3). As shown in the Figure 3A, MEHA at the dose of $200 \mathrm{mg} / \mathrm{kg}$ and $400 \mathrm{mg} / \mathrm{kg}$ significantly enhanced the time spent $(p<0.001)$ in the open arms $(191.33 \pm 2.43$ and $248 \pm 2.08 \mathrm{~s}$, respectively) indicating anxiolytic effects. Understandably, the time spent in the closed arms of extract treated mice were less (Figure 3B).

A

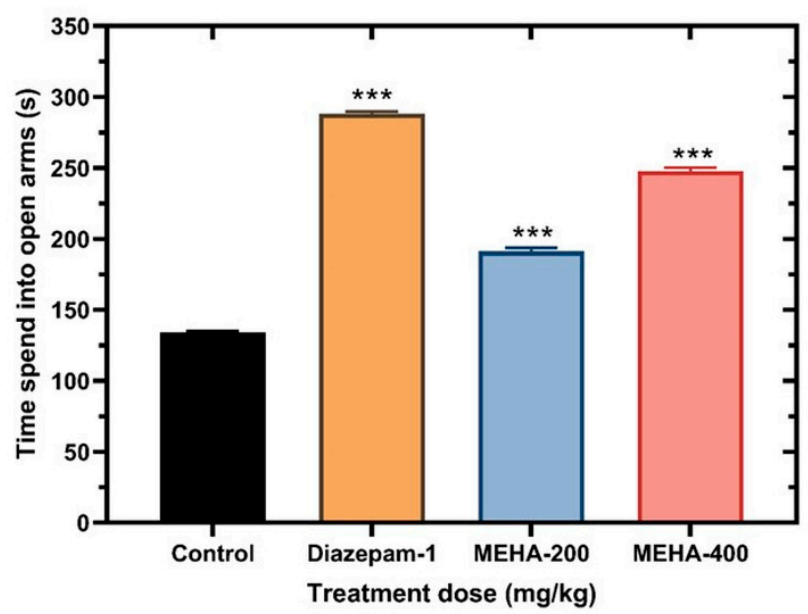

B

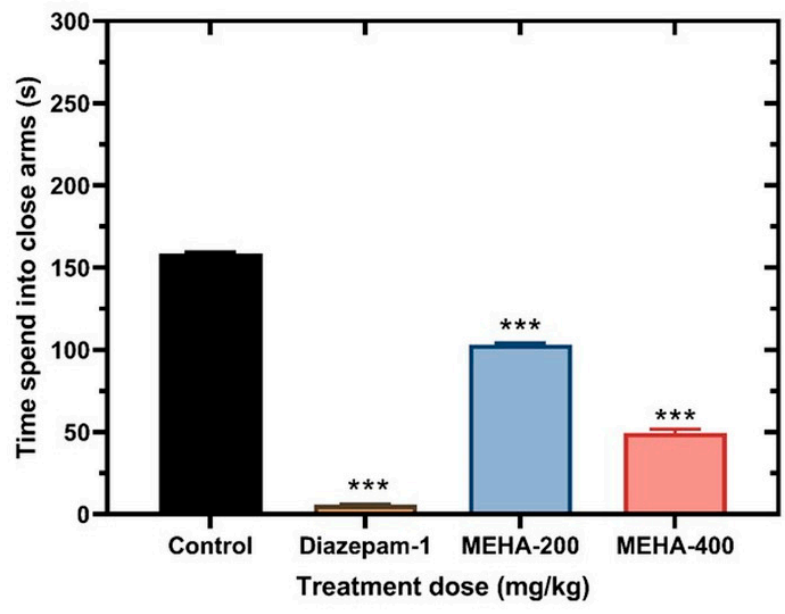

Figure 3. Anxiolytic activity of MEHA on elevated plus maze test in mice. Time spend in open arm (A), time spends in closed arms (B). Results are expressed in mean \pm SEM. ${ }^{* * *} p<0.001$, significantly different from control; ANOVA followed by Dunnett's test ( $n=3$, per group). MEHA: methanol extract of Homalomena aromatica ( $200 \mathrm{mg} / \mathrm{kg}$ and $400 \mathrm{mg} / \mathrm{kg}$ ); Reference drug diazepam $1 \mathrm{mg} / \mathrm{kg}$. 
Likewise, the hole board experiment used to show the anxiolytic effect of the extract. After treatment, the head dipping number was increased efficiently in case of diazepam as well as extract administered animals compared to the control. The MEHA at both dose levels showed an increase in the number of head dipping events whereas $400 \mathrm{mg} / \mathrm{kg}$ produced a significant upsurge $(42.67 \pm 3.48)$ as compared to the control animals $(p<0.01)$ (Figure 4).

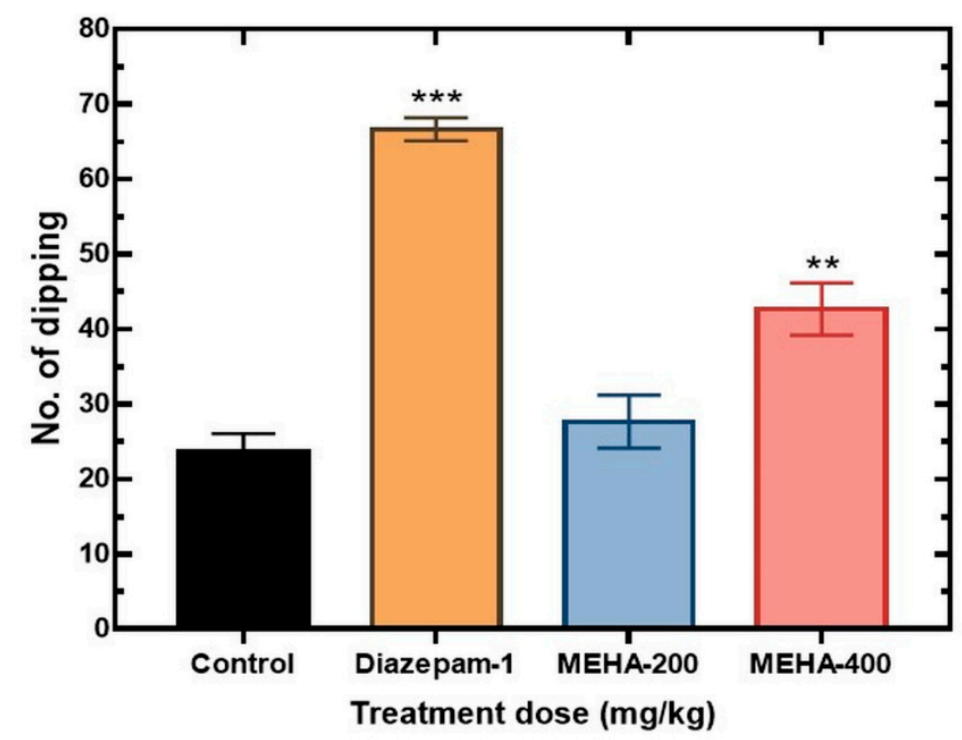

Figure 4. Anxiolytic activity of MEHA on hole board test in mice. Results are expressed in mean \pm SEM. ${ }^{* *} p<0.01$ and ${ }^{* *} p<0.001$, significantly different from control; ANOVA followed by Dunnett's test ( $n=3$, per group). MEHA: methanol extract of Homalomena aromatica leaves (200 mg $/ \mathrm{kg}$ and $400 \mathrm{mg} / \mathrm{kg}$ ); Reference drug diazepam $1 \mathrm{mg} / \mathrm{kg}$.

\subsection{Antidepressant Activity}

In our exploration, besides anxiolytic activity, MEHA showed antidepressant activity which was evaluated through forced swim and tail suspension tests. These two tests are very convenient and the most widely used validated animal models for the evaluation of substances with potential antidepressant-like activities as well as to identify the pathological mechanism(s) of depression [36,37].

A recent investigation suggest that stressful conditions activate the hypothalamicpituitary-adrenal axis which in turn stimulates the periventricular neurons to release corticotrophin-releasing factors [38]. As it is well known depression symptoms are revealed due to overactivation of the hypothalamic-pituitary-adrenal axis, causing abnormal regulation of corticotrophin-releasing factors resulting in the suppression of the adrenocorticotropic hormone response and elevated cerebrospinal fluid levels [39]. Moreover, several neurotransmitters including serotonin, noradrenalin, dopamine, and GABA are involved in the pathophysiology of depressive illness. Thus, it is also believed that depression is due to the deficiency of one or another of these neurotransmitters [40]. Successful antidepressants act by suppressing stress-induced hypothalamic-pituitary-adrenal axis activation and restoring the normal flow of neurotransmitters [41]. In forced swim experiments, when mice are forced to swim in a confined condition, they become immobile after an initial period of struggling. This inevitable stressful condition is evaluated as the parameter to measure the activity of antidepressant agents. In this test (Figure 5A), animals treated with two doses of MEHA (200 and $400 \mathrm{mg} / \mathrm{kg}$, p.o) showed decreases in their immobility times, which was significant (120.33 $\pm 2.03 \mathrm{~s}$ and $96.67 \pm 2.96 \mathrm{~s}$, respectively) when compared with control $(198.67 \pm 1.76 \mathrm{~s})$. Animals treated with imipramine hydrochloride $(10 \mathrm{mg} / \mathrm{kg})$, as expected, showed a significant decrease in their immobility time (66.67 $\pm 0.89 \mathrm{~s})$. Similarly, the tail suspension assay is another primary screening test for detecting antidepressant 
activity of a substance. This test induces a state of despair in animals similar to that of forced swim test. In the tail suspension test (Figure 5B), animals were treated with 200 and $400 \mathrm{mg} / \mathrm{kg}$ doses of MEHA showed decreases in their immobility times $(177.00 \pm 2.16 \mathrm{~s}$ and $87.33 \pm 1.96 \mathrm{~s}$, respectively) which was significant as compared to control (202.33 $\pm 2.896 \mathrm{~s})$, while animals treated with imipramine hydrochloride $(10 \mathrm{mg} / \mathrm{kg})$, also showed a significant decrease in their immobility time $(82.33 \pm 1.29 \mathrm{~s})$. This evidence suggest that MEHA has the ability to suppress depression and anxiety in mice.

A

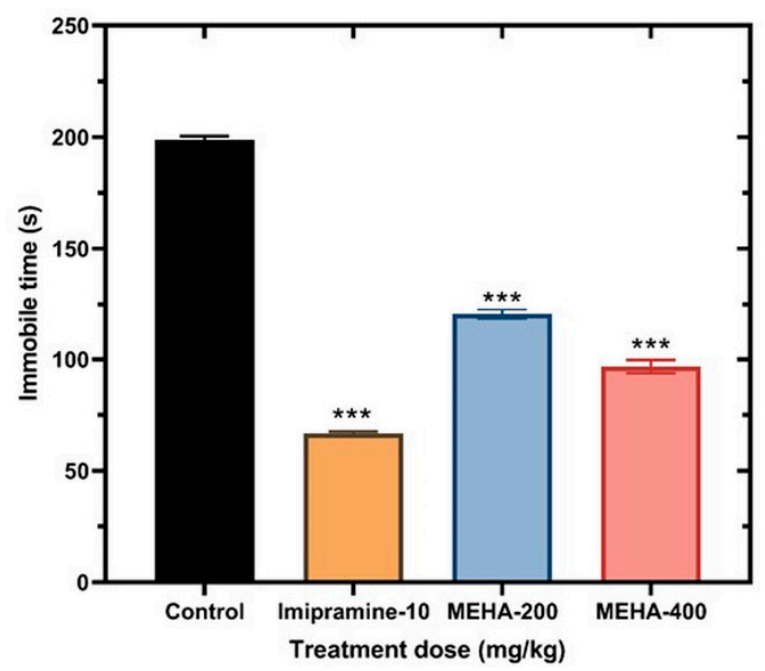

B

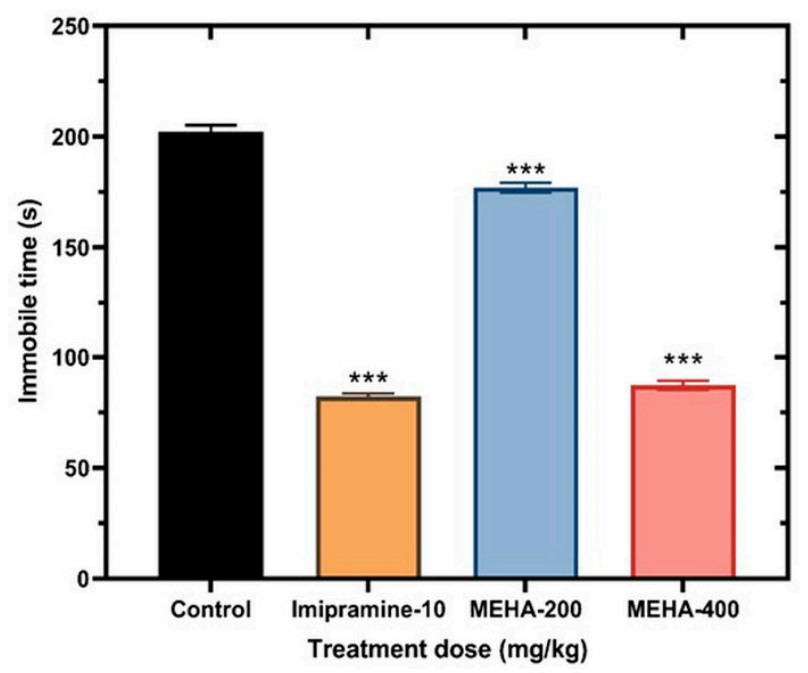

Figure 5. Antidepressant activity of MEHA on tail suspension (A) and forced swimming (B) tests in mice. Results are expressed in mean \pm SEM. ${ }^{* * *} p<0.001$, significantly different from control; ANOVA followed by Dunnett's test $(n=3$, per group). MEHA: methanol extract of Homalomena aromatica leaves; MEHA-200, methanol extract of H. aromatica $200 \mathrm{mg} / \mathrm{kg}$; MEHA-400, methanol extract of H. aromatica $400 \mathrm{mg} / \mathrm{kg}$; Reference drug imipramine hydrochloride $(10 \mathrm{mg} / \mathrm{kg})$.

\subsection{In Silico Studies}

Contacts between ligand and protein are fundamental to all organic processes. By means of these interactions, living entities maintain all types of regulatory and metabolic systems that together organize their lifecycle processes. To predict and understand all off these biological processes, computer-aided analyses: molecular docking, homological modeling, molecular dynamics and simulations are widely used scientific tools because these methods are economic and time saving. The target molecules can be also utilized as bioactive substances for modification and controlling the bio-mechanism in an in silico medium. To make our findings more relevant, we conducted an in silico molecular docking investigation targeting xanthine oxidoreductase (PDB: $2 \mathrm{CKJ}$ ) to determine antioxidant properties, tissue plasminogen activator receptor (PDB: $1 \mathrm{~A} 5 \mathrm{H})$ for thrombolytic activity, potassium channel receptor (PDB: 4UUJ) for anxiolytic properties, and human serotonin receptor (PDB: 5I6X) for antidepressant activity. In this analysis, four widely used standard agents-ascorbic acid, streptokinase, diazepam and imipramine hydrochloride-were selected to compare the docking scores with the compounds obtained from essential oils from the leaves of $H$. aromatica.

In the case of the computer-aided antioxidant docking study, the outcomes of the docking investigation against xanthine oxidoreductase for antioxidant activity are shown in Table 2. 4-Terpineol $(-6.457 \mathrm{kcal} / \mathrm{mol})$ and T-cadinol $(-6.882 \mathrm{kcal} / \mathrm{mol})$ showed better docking scores than ascorbic acid $(-6.407 \mathrm{kcal} / \mathrm{mol})$. Contrariwise, bullatantriol $(-6.260 \mathrm{kcal} / \mathrm{mol})$ and oplodiol $(-6.182 \mathrm{kcal} / \mathrm{mol})$ also demonstrated good binding scores close to ascorbic acid. T-Cadinol showed the best docking score among all compounds in our antioxidant assays along with standard drugs by interacting with one hydrogen 
bond (LEU257) and six hydrophobic bonds (LEU257, ALA301, ILE353, LEU257, ILE403 and LEU404) showed in Figure 6. The compound named $\alpha$-cadinene did not bind with xanthine oxidoreductase.

Table 2. Docking score of the phytochemical compounds of essential oil in leaves of H. aromatica against xanthine oxidoreductase (PDB: 2CKJ) for antioxidant activity (Bold indicates lower docking score).

\begin{tabular}{|c|c|c|c|}
\hline Compounds & $\begin{array}{l}\text { Binding Score } \\
\text { (kcal/mol) }\end{array}$ & $\begin{array}{l}\text { Glide Emodel } \\
\text { (kcal/mol) }\end{array}$ & $\begin{array}{l}\text { Glide Energy } \\
\text { (kcal/mol) }\end{array}$ \\
\hline 1,2-Dimethylbenzene & -4.214 & -15.464 & -13.480 \\
\hline 4-Terpineol & -6.457 & -23.043 & -16.968 \\
\hline$\alpha$-Cadinene & - & - & - \\
\hline$\alpha$-Pinene & -4.487 & -12.354 & -11.451 \\
\hline Bullatantriol & -6.260 & -34.646 & -27.570 \\
\hline Camphene & -4.470 & -7.083 & -6.289 \\
\hline cis-Linalool oxide & -4.825 & -30.566 & -24.083 \\
\hline Cryptone & -5.259 & -24.619 & -19.376 \\
\hline Linalyl acetate & -5.116 & -34.935 & -29.617 \\
\hline Nerol & -4.505 & -26.080 & -23.519 \\
\hline Oplodiol & -6.182 & -33.777 & -25.516 \\
\hline Spatulenol & -5.343 & -24.144 & -19.953 \\
\hline T-Cadinol & -6.882 & -32.631 & -24.531 \\
\hline Ascorbic acid & -6.407 & - & - \\
\hline
\end{tabular}

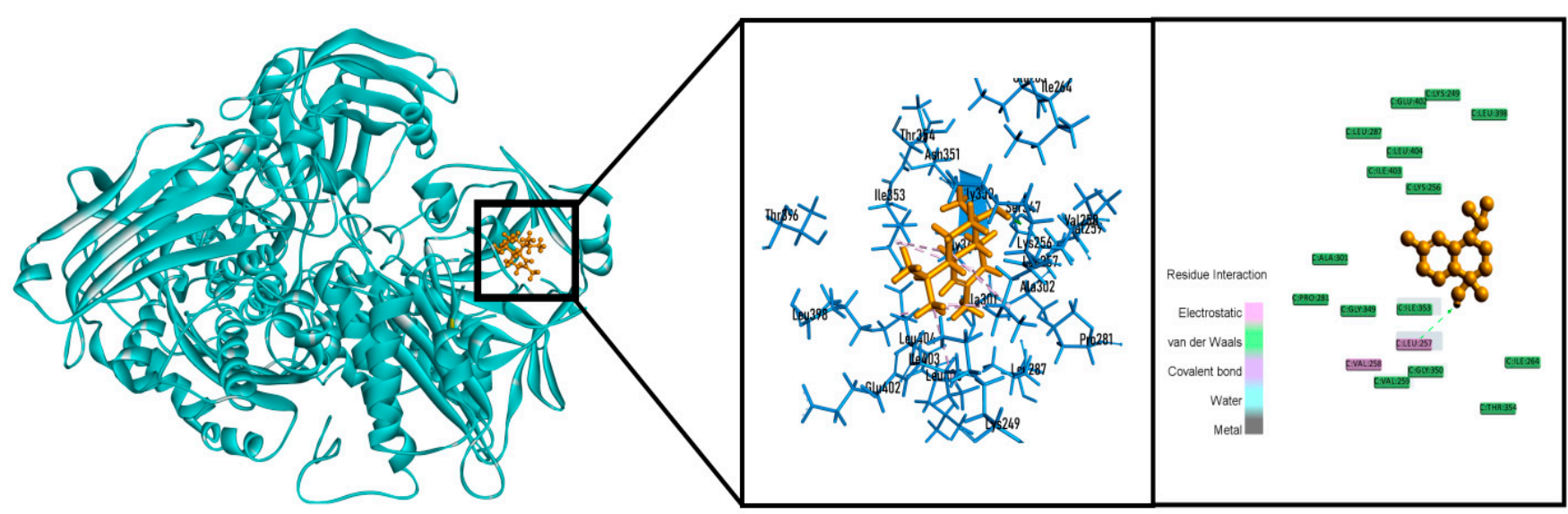

Figure 6. Best docked poses and 2D interactions of T-cadinol with xanthine oxidoreductase (PDB: 2CKJ) for antioxidant activity.

In thrombolytic docking assay, 4-terpineol $(-5.254 \mathrm{kcal} / \mathrm{mol}), \alpha$-cadinene $(-5.720 \mathrm{kcal} /$ $\mathrm{mol})$, spatulenol $(-6.190 \mathrm{kcal} / \mathrm{mol})$ and T-cadinol $(-6.300 \mathrm{kcal} / \mathrm{mol})$ showed better biding affinity than streptokinase $(-5.102 \mathrm{kcal} / \mathrm{mol})$ against tissue plasminogen activator receptor (Table 3). Among them T-cadinol exhibited the best result by interacting with two hydrogen bonds (SER195 and GLN192) and one hydrophobic bond (CYS220) (Figure 7). 
Table 3. Docking score of the phytochemical compounds of essential oil in leaves of H. aromatica against tissue plasminogen activator receptor (PDB: 1A5H) for thrombolytic activity (Bold indicates lower docking score).

\begin{tabular}{|c|c|c|c|}
\hline Compound & $\begin{array}{l}\text { Binding Score } \\
(\mathrm{kcal} / \mathrm{mol})\end{array}$ & $\begin{array}{l}\text { Glide Emodel } \\
\text { (kcal/mol) }\end{array}$ & $\begin{array}{l}\text { Glide Energy } \\
\text { (kcal/mol) }\end{array}$ \\
\hline 1,2-Dimethylbenzene & -4.260 & -19.110 & -15.447 \\
\hline 4-Terpineol & -5.254 & -25.836 & -20.179 \\
\hline$\alpha$-Cadinene & -5.720 & -34.444 & -25.730 \\
\hline$\alpha$-Pinene & -3.975 & -19.073 & -15.385 \\
\hline Bullatantriol & -4.350 & -31.223 & -25.604 \\
\hline Camphene & -3.825 & -20.110 & -16.344 \\
\hline cis-Linalool oxide & -3.794 & -27.360 & -23.111 \\
\hline Cryptone & -4.537 & -25.031 & -19.913 \\
\hline Linalyl acetate & -2.781 & -24.314 & -21.364 \\
\hline Nerol & -2.702 & -24.865 & -21.837 \\
\hline Oplodiol & -5.075 & -32.355 & -25.009 \\
\hline Spatulenol & -6.190 & -31.911 & -25.145 \\
\hline T-Cadinol & -6.300 & -35.571 & -26.388 \\
\hline Streptokinase & -5.102 & - & - \\
\hline
\end{tabular}

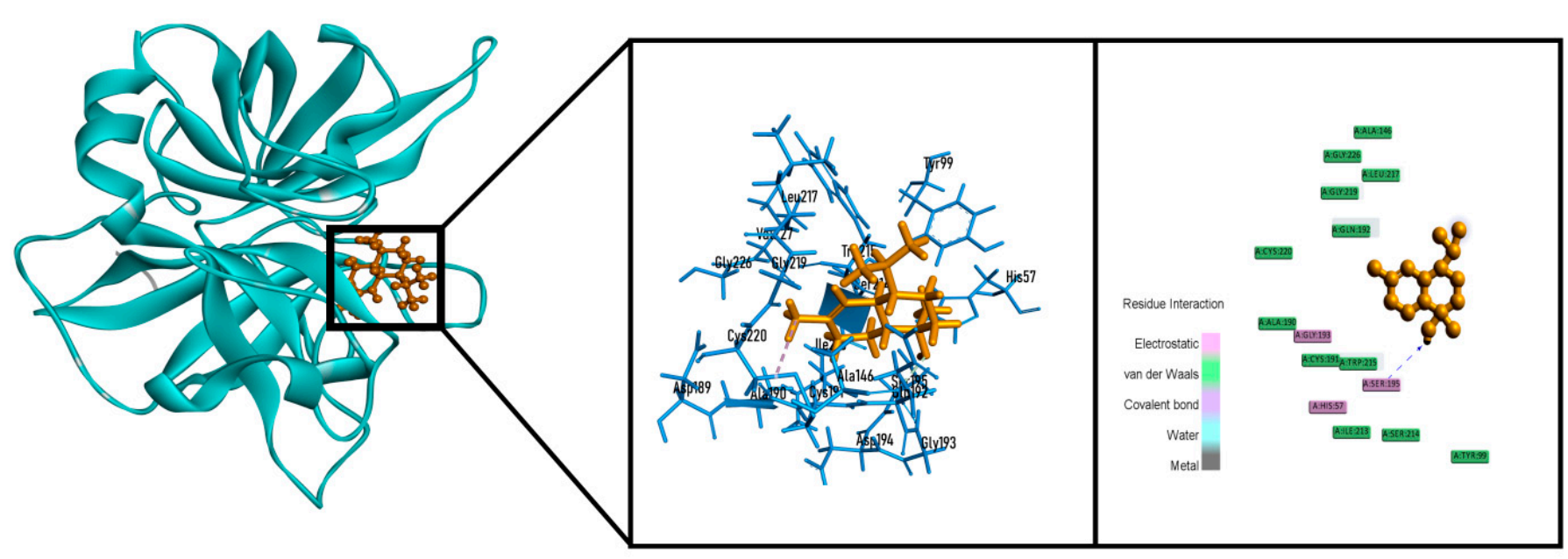

Figure 7. Best docked poses and 2D interactions of T-cadinol tissue plasminogen activator receptor (PDB: $1 \mathrm{~A} 5 \mathrm{H})$ for thrombolytic activity.

In our anxiolytic docking investigation 1, 2-dimethylbenzene (-3.658 kcal/mol), 4terpineol $(-5.143 \mathrm{kcal} / \mathrm{mol}), \alpha$-cadinene $(-3.442 \mathrm{kcal} / \mathrm{mol})$, bullatantriol $(-4.098 \mathrm{kcal} / \mathrm{mol})$, cryptone $(-3.512 \mathrm{kcal} / \mathrm{mol})$ and $\alpha$-linalool oxide $(-3.691 \mathrm{kcal} / \mathrm{mol})$ demonstrated better binding attraction than diazepam $(-3.140 \mathrm{kcal} / \mathrm{mol})$ against potassium channel receptor (Table 4). Whereas, 4-terpineol showed best score by interacting with one hydrogen bond (leu86) and one hydrophobic bond (ALA54) (Figure 8). 
Table 4. Docking score of the phytochemical compounds of essential oil in leaves of $H$. aromatica with potassium channel receptor (PDB: 4UUJ) for anxiolytic activity (Bold indicates lower docking score).

\begin{tabular}{cccc}
\hline Compounds & $\begin{array}{c}\text { Binding Score } \\
\text { (kcal/mol) }\end{array}$ & $\begin{array}{c}\text { Glide Emodel } \\
\text { (kcal/mol) }\end{array}$ & $\begin{array}{c}\text { Glide Energy } \\
\text { (kcal/mol) }\end{array}$ \\
\hline 1,2-Dimethylbenzene & -3.658 & -11.707 & -9.535 \\
4-Terpineol & -5.143 & -24.454 & -20.685 \\
--Cadinene & -3.691 & -12.544 & -10.088 \\
$\alpha$-Pinene & -2.928 & -12.540 & -10.571 \\
Bullatantriol & -4.098 & -23.075 & -16.971 \\
Camphene & -2.884 & -11.854 & -10.084 \\
cis-Linalool oxide & -3.512 & -25.666 & -21.378 \\
Cryptone & -3.442 & -18.344 & -14.733 \\
Linalyl acetate & -1.155 & -16.838 & -16.182 \\
Nerol & -2.924 & -24.224 & -21.507 \\
Oplodiol & - & - & - \\
Spatulenol & -2.810 & -17.092 & -14.612 \\
T-Cadinol & -2.457 & -6.109 & -5.696 \\
Diazepam & 3.140 & - & - \\
\hline
\end{tabular}

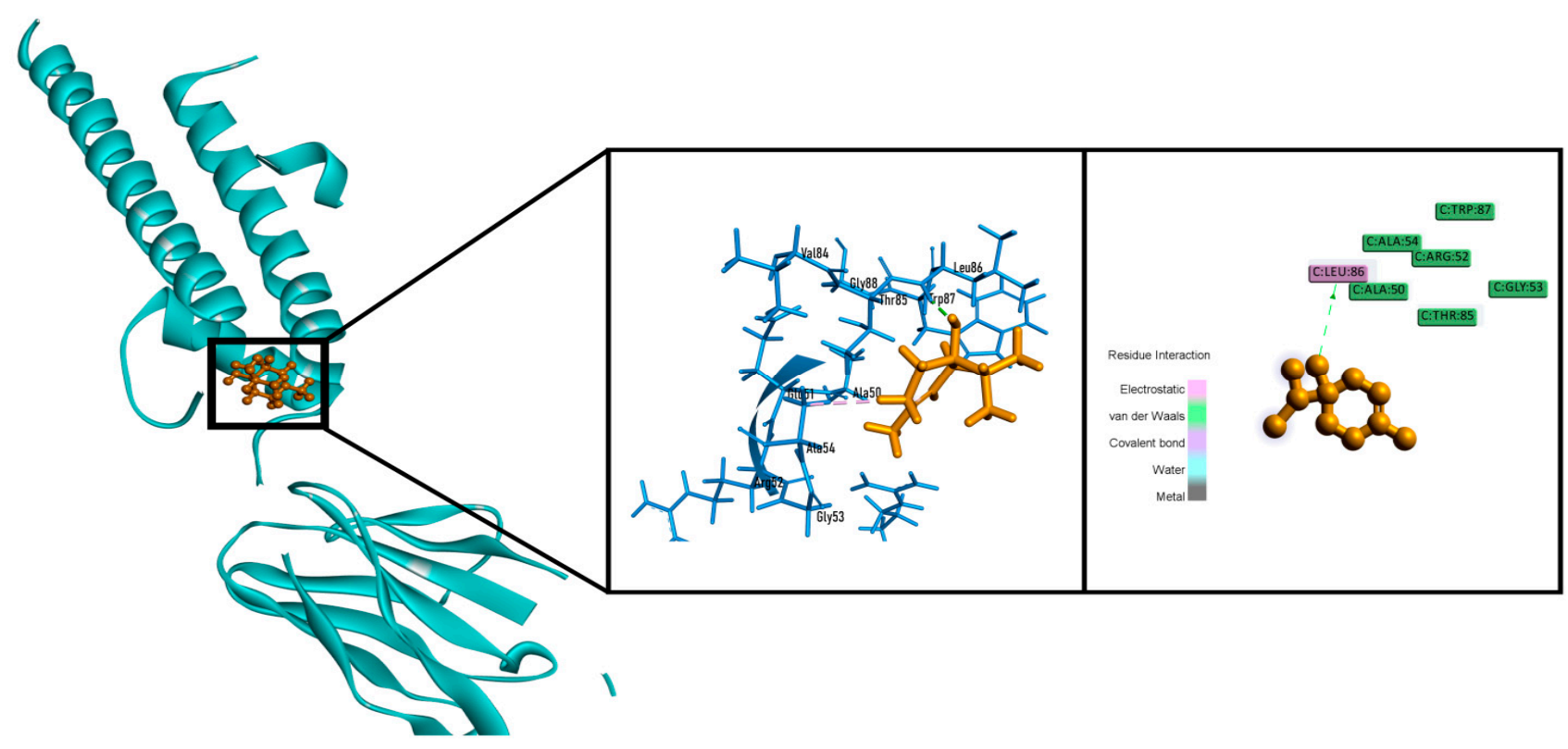

Figure 8. Best docked poses and 2D interactions of 4-terpineol with potassium channel receptor (PDB: 4UUJ) for anxiolytic activity.

In the case of the antidepressant activity assay, the compounds T-cadinol $(-6.892 \mathrm{kcal} /$ $\mathrm{mol})$, oplodiol $(-6.948 \mathrm{kcal} / \mathrm{mol})$ and $\alpha$-cadinene $(-7.188 \mathrm{kcal} / \mathrm{mol})$ of essential oils in leaves of $H$. aromatica showed the docking score near about while standard drug imipramine hydrochloride has $8.171 \mathrm{kcal} / \mathrm{mol}$ docking score (Table 5). $\alpha$-Cadinene presented a better docking score than other compounds present in leaves of $H$. aromatica against human serotonin receptor by interacting with four hydrophobic bonds (ILE172, VAL501, TYR95 and PHE341) (Figure 9). 
Table 5. Docking score of the phytochemical compounds of essential oil in leaves of H. aromatica with human serotonin receptor (PDB: 5I6X) for antidepressant activity (bold indicates lower docking score).

\begin{tabular}{|c|c|c|c|}
\hline Compounds & $\begin{array}{l}\text { Binding Score } \\
(\mathrm{kcal} / \mathrm{mol})\end{array}$ & $\begin{array}{l}\text { Glide Emodel } \\
\text { (kcal/mol) }\end{array}$ & $\begin{array}{l}\text { Glide Energy } \\
\text { (kcal/mol) }\end{array}$ \\
\hline 1,2-Dimethylbenzene & -6.105 & -27.029 & -19.783 \\
\hline 4-Terpineol & -5.078 & -27.507 & -20.217 \\
\hline$\alpha$-Cadinene & -7.188 & -37.235 & -27.179 \\
\hline$\alpha$-Pinene & -5.426 & -21.376 & -16.141 \\
\hline Bullatantriol & -6.070 & -43.055 & -32.486 \\
\hline Camphene & -5.729 & -26.921 & -19.908 \\
\hline cis-Linalool oxide & -5.418 & -38.724 & -29.151 \\
\hline Cryptone & -5.946 & -27.914 & -20.359 \\
\hline Linalyl acetate & -3.648 & -31.580 & -26.453 \\
\hline Nerol & -4.254 & -29.861 & -24.531 \\
\hline Oplodiol & -6.948 & -39.856 & -29.137 \\
\hline Spatulenol & -5.796 & -32.639 & -23.429 \\
\hline T-Cadinol & -6.892 & -40.513 & -28.388 \\
\hline $\begin{array}{l}\text { Imipramine } \\
\text { hydrochloride }\end{array}$ & 8.171 & - & - \\
\hline
\end{tabular}

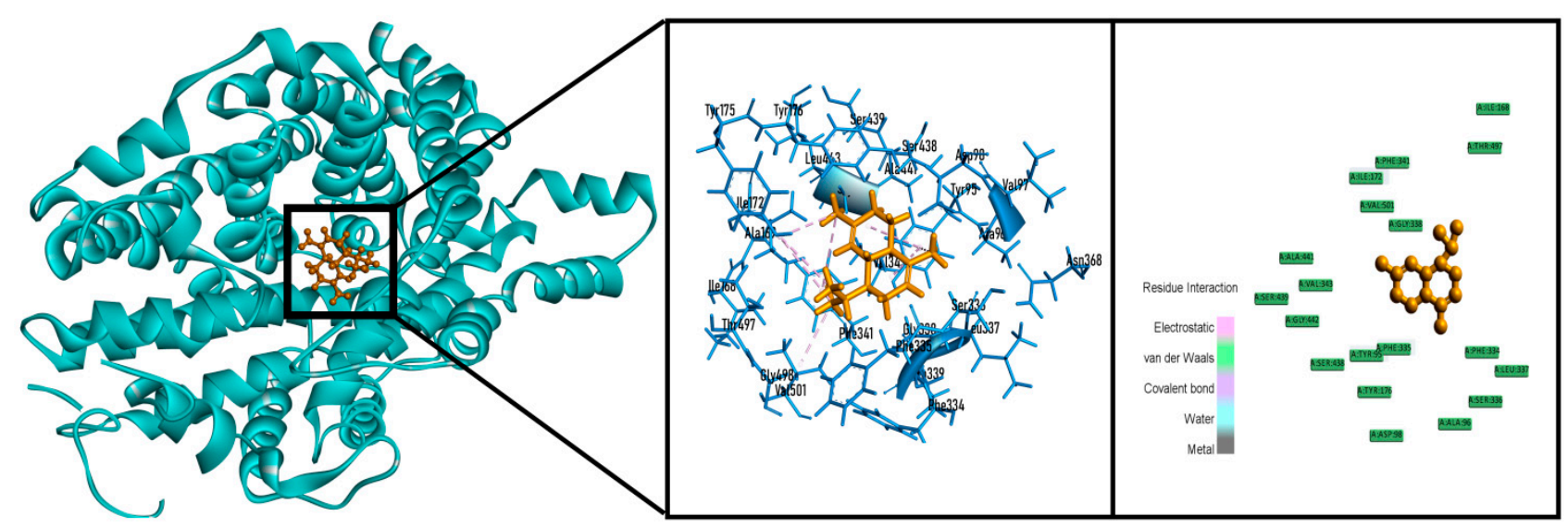

Figure 9. Best docked poses and 2D interactions of alpha-Cadinene with human serotonin receptor (PDB: 5I6X) for antidepressant activity.

From these above outcomes, it can be concluded that the studied phytochemicals of the MEHA may in part be accountable for the antioxidant, thrombolytic, anxiolytic and antidepressant activities through interfaces with these objective receptors.

There are three major compounds which have been identified based on the computational study showing the best docking scores (Figure 10). It has been observed that T-cadinol showed the best results in the antioxidant as well as thrombolytic assays against xanthine oxidoreductase and tissue plasminogen activator receptor, respectively. The compound 4-terpineol exhibited the best anxiolytic results while $\alpha$-cadinene displayed the greatest binding affinity for antidepressant activity. Moreover, It has been previously reported that essentials oils have the capability to show thrombolytic [42], anxiolytic [43] and antidepressant [44] activities. 


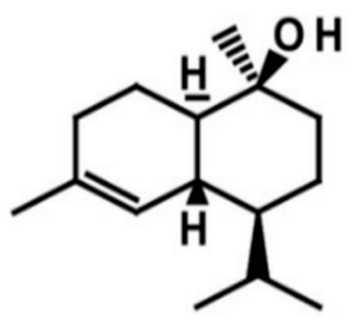

T-cadinol

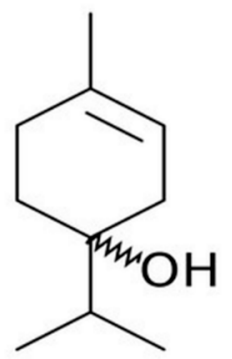

4-terpineol

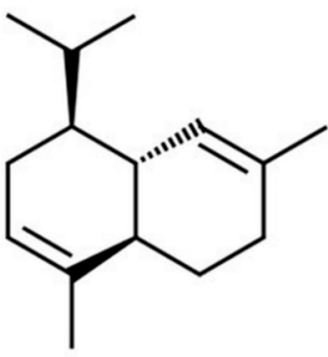

Alpha-cadinene

Figure 10. Chemical structures of major compounds identified based on computational study.

According to their uppermost docking score against xanthine oxidoreductase, human serotonin receptor, potassium channel receptor, tissue plasminogen activator receptor, we have selected 13 phytocompounds in order to find their probable pharmacokinetic factors from drug likeness point of views with their toxicological properties. These sort of categorizations are considered to be a vital phase in the drug development process because it saves time in clinical trials besides expenditures of money. In the current study, SwissADME, an online tool was, used to estimate the pharmacokinetic properties of the 13 selected compounds based on Lipinski's rule of five and Veber's rules (Table 6). Oral bioavailability is the vital feature for the development of novel candidate. As described by Lipinski's rules, an orally introduced drug should have a MW $<500 \mathrm{amu}$, HBA sites $<10$, HBD sites $<5$, and, $\log P \leq 5$, whereas Veber et al. recommend that a drug candidate should have the nRB value $\leq 10$ and TPSA value $\leq 140 \AA^{2}$ [45]. If any compounds violate one of these rules, it cannot be considered a perfect therapeutic agent. Surprisingly, none of the compounds violated these rules in this study. This indicates that all of the compounds have good oral bioavailability and could be considered as possible candidates for the next drug development.

Table 6. ADME profiling of the phytochemical compounds of essential oil in leaves of H. aromatica.

\begin{tabular}{|c|c|c|c|c|c|c|c|}
\hline \multirow[b]{2}{*}{ Compounds } & \multicolumn{4}{|c|}{ Lipinski Rules } & \multirow{2}{*}{$\begin{array}{l}\text { Lipinski's } \\
\text { Violations } \\
\quad \leq 1\end{array}$} & \multicolumn{2}{|c|}{ Veber Rules } \\
\hline & $\begin{array}{c}\text { MW } \\
\text { (g/mol) } \\
<500\end{array}$ & $\begin{array}{c}\text { HBA } \\
<10\end{array}$ & $\begin{array}{c}\text { HBD } \\
<5\end{array}$ & $\begin{array}{c}\log P \\
\leq 5\end{array}$ & & $\begin{array}{l}\text { nRB } \\
\leq 10\end{array}$ & $\begin{array}{l}\text { TPSA } \\
\leq 140\end{array}$ \\
\hline 1,2-Dimethylbenzene & 106.17 & 0 & 0 & 2.03 & No & 0 & $0.00 \AA^{2}$ \\
\hline 4-Terpineol & 154.25 & 1 & 1 & 2.51 & No & 1 & $20.23 \AA^{2}$ \\
\hline$\alpha$-Cadinene & 204.35 & 0 & 0 & 3.38 & No & 1 & $0.00 \AA^{2}$ \\
\hline$\alpha$-Cadinol & 222.37 & 1 & 1 & 3.15 & No & 1 & $20.23 \AA^{2}$ \\
\hline$\alpha$-Pinene & 136.23 & 0 & 0 & 2.63 & No & 0 & $0.00 \AA^{2}$ \\
\hline Bullatantriol & 256.38 & 3 & 3 & 2.60 & No & 2 & $60.69 \AA^{2}$ \\
\hline Camphene & 136.23 & 0 & 0 & 2.58 & No & 0 & $0.00 \AA^{2}$ \\
\hline cis-Linalool oxide & 170.25 & 2 & 1 & 2.45 & No & 2 & $29.46 \AA^{2}$ \\
\hline Cryptone & 138.21 & 1 & 0 & 2.05 & No & 1 & $17.07 \AA^{2}$ \\
\hline Linalyl acetate & 196.29 & 2 & 0 & 3.08 & No & 6 & $26.30 \AA^{2}$ \\
\hline Nerol & 154.25 & 1 & 1 & 2.75 & No & 4 & $20.23 \AA^{2}$ \\
\hline Oplodiol & 238.37 & 2 & 2 & 2.98 & No & 1 & $40.46 \AA^{2}$ \\
\hline Spatulenol & 220.35 & 1 & 1 & 2.88 & No & 0 & $20.23 \AA^{2}$ \\
\hline T-Cadinol & 222.37 & 1 & 1 & 3.15 & No & 1 & $20.23 \AA^{2}$ \\
\hline
\end{tabular}

MW, Molecular weight; HBA, Hydrogen bond acceptor; HBD, Hydrogen bond donor; Log P, Lipophilicity; nRB, Number of rotable bond; TPSA, Topological polar surface area.

Furthermore, the admetSAR online tool was used to predict the toxicological properties of the 13 selected compounds. Results of the present study showed that except for $\alpha$-cadinene and linalyl acetate none of the substances posed a risk of Ames toxicity, carcino- 
genicity, acute oral toxicity, and weak rat acute toxicity (Table 7). Additionally all of these 13 compounds demonstrated comparatively close human oral bioavailability and human intestinal absorption rate as standard drugs (Table 8). As a result, all 13 phytochemicals could be considered for potential therapeutic candidates with good oral bioavailability though advanced studies are still obligatory.

Table 7. Toxicological properties of the phytochemical compounds of essential oil in leaves of H. aromatica.

\begin{tabular}{|c|c|c|c|c|c|}
\hline \multirow{2}{*}{\multicolumn{2}{|c|}{ Compounds }} & \multicolumn{4}{|c|}{ Parameters } \\
\hline & & $\begin{array}{l}\text { Ames } \\
\text { Toxicity }\end{array}$ & Carcinogens & $\begin{array}{l}\text { Acute Oral } \\
\text { Toxicity }\end{array}$ & $\begin{array}{l}\text { Rat Acute Toxicity } \\
\left.\text { (LD }{ }_{50}, \mathrm{~mol} / \mathrm{kg}\right)\end{array}$ \\
\hline & 1,2-Dimethylbenzene & NAT & $\mathrm{NC}$ & III & 1.5513 \\
\hline & 4-Terpineol & NAT & $\mathrm{NC}$ & III & 2.0424 \\
\hline & $\alpha$-Cadinene & AT & $\mathrm{NC}$ & III & 1.4298 \\
\hline & $\alpha$-Cadinol & NAT & $\mathrm{NC}$ & III & 2.2009 \\
\hline & $\alpha$-Pinene & NAT & $\mathrm{NC}$ & III & 1.5348 \\
\hline & Bullatantriol & NAT & $\mathrm{NC}$ & III & 2.8543 \\
\hline & Camphene & NAT & $\mathrm{NC}$ & III & 1.4664 \\
\hline & cis-Linalool oxide & NAT & $\mathrm{NC}$ & III & 2.1384 \\
\hline & Cryptone & NAT & $\mathrm{NC}$ & III & 1.8337 \\
\hline & Linalyl acetate & NAT & $\mathrm{C}$ & IV & 1.4627 \\
\hline & Nerol & NAT & $\mathrm{NC}$ & III & 1.6146 \\
\hline & Oplodiol & NAT & $\mathrm{NC}$ & III & 2.9423 \\
\hline & Spatulenol & NAT & $\mathrm{NC}$ & III & 2.5610 \\
\hline & T-Cadinol & NAT & $\mathrm{NC}$ & III & 2.2009 \\
\hline \multirow{4}{*}{ Standards } & Ascorbic acid & NAT & $\mathrm{NC}$ & IV & 1.3059 \\
\hline & Streptokinase & NAT & $\mathrm{NC}$ & II & 2.2785 \\
\hline & Diazepam & NAT & $\mathrm{NC}$ & II & 2.5946 \\
\hline & Imipramine hydrochloride & NAT & $\mathrm{NC}$ & III & 2.8931 \\
\hline
\end{tabular}

NAT, Non-Ames toxic; AT, Ames toxic; C, Carcinogenic; NC, Non-carcinogenic. Category-I means ( $\mathrm{LD}_{50} \leq 50 \mathrm{mg} / \mathrm{kg}$ ) and Category-III (500 $\mathrm{mg} / \mathrm{kg} \mathrm{LD} 505000 \mathrm{mg} / \mathrm{kg})$.

Table 8. Additional pharmacokinetic profiling (absorption and oral bioavailability) of the phytochemical compounds of essential oil in leaves of H. aromatica.

\begin{tabular}{|c|c|c|c|}
\hline & Compounds & $\begin{array}{c}\text { Human Intestinal } \\
\text { Absorption }\end{array}$ & $\begin{array}{c}\text { Human Oral } \\
\text { Bioavailability }\end{array}$ \\
\hline & 1,2-Dimethylbenzene & 0.9801 & 0.9143 \\
\hline & 4-Terpineol & 0.9842 & 0.6286 \\
\hline & $\alpha$-Cadinene & 0.9778 & 0.7429 \\
\hline & $\alpha$-Cadinol & 0.9892 & 0.5143 \\
\hline & $\alpha$-Pinene & 0.9677 & 0.8286 \\
\hline & Bullatantriol & 0.9841 & 0.6571 \\
\hline & Camphene & 0.9677 & 0.6286 \\
\hline & cis-Linalool oxide & 0.9626 & 0.5857 \\
\hline & Cryptone & 0.9905 & 0.6857 \\
\hline & Linalyl acetate & 0.9703 & 0.6143 \\
\hline & Nerol & 0.9681 & 0.5429 \\
\hline & Oplodiol & 0.9896 & 0.5857 \\
\hline & Spatulenol & 0.9906 & 0.7330 \\
\hline & T-Cadinol & 0.9892 & 0.5143 \\
\hline \multirow{4}{*}{ Standards } & Ascorbic acid & 0.8150 & 0.5857 \\
\hline & Streptokinase & 0.4612 & 0.5857 \\
\hline & Diazepam & 0.9948 & 0.9286 \\
\hline & Imipramine hydrochloride & 0.9920 & 0.7286 \\
\hline
\end{tabular}




\section{Materials and Methods}

\subsection{Reagents, Chemicals and Instruments}

Analytical grade chemicals were used in all the experiments. Methanol, ascorbic acid, DPPH (1,1-diphenyl-2-picrylhydrazyl), Folin-Ciocalteau reagent (FCR), sodium carbonate, gallic acid, potassium acetate, aluminium chloride, quercetin were purchased from Sigma Chemicals (St. Louis, MO, USA). Streptokinase, Tween 80, diazepam, imipramine hydrochloride were received from Square Pharmaceuticals Ltd. (Dhaka, Bangladesh). A UV-spectrophotometer (UVmini-1240, Shimadzu, Shimadzu Corporation, Kyoto, Japan) was used for absorbance measurements.

\subsection{Collection, Identification and Preparation of Extract}

Leaves of the H. aromatica were collected from Kaptai, Sitapahar, Chittagong, Bangladesh in the month of February 2018. It was identified by Dr. Shaikh Bokhtear Uddin, Professor, Department of Botany, University of Chittagong, Chittagong-4331, Bangladesh. The voucher specimen (accession number: 3286) was deposited in the herbarium center of University of Chittagong. The collected fresh leaves were washed and cut into small pieces and dried under shade for a week. Final dried was carried out in an oven at $40-45{ }^{\circ} \mathrm{C}$ for $24 \mathrm{~h}$. A grinder was used to grind the dried leaves into coarse powder. The ground leaves were soaked in adequate amount of methanol for a week at room temperature with vigorous shaking and stirring. The solution was filtered through a cotton-plugged funnel followed by Whatman filter paper number 1. Finally, with the help of rotary evaporator the solvent was evaporated. The viscous mass was kept in a freezer $\left(-20^{\circ} \mathrm{C}\right)$ until further use.

\subsection{Antioxidant Activity}

DPPH (1,1-diphenyl-2-picrylydrazyl) Radical Scavenging Activity

DPPH free radical scavenging activity of MEHA was assessed by following the method of Braca et al. [46]. This method has been simplified by Adnan et al. [47]. Briefly, MEHA $(100 \mu \mathrm{L})$ at various concentrations $(50-800 \mu \mathrm{g} / \mathrm{mL})$ were added to $3 \mathrm{~mL}$ of a $0.004 \%$ methanol solution of DPPH. After $30 \mathrm{~min}$ incubation absorbance was measured at $517 \mathrm{~nm}$ and percentage of scavenging activity was determined by using the equation: Percentage $(\%)$ of scavenging activity $=\left[\left(\mathrm{A}_{0}-\mathrm{A}_{1}\right) / \mathrm{A}_{0}\right] \times 100$. Where, $\mathrm{A}_{0}$ is the absorbance of control and $A_{1}$ is the absorbance of extract sample. After preparing the curve, $\mathrm{IC}_{50}$ value was calculated using linear regression analysis. The result was obtained in triplicate and expressed as mean $\pm \mathrm{SEM}$.

\subsection{Total Phenolics Content}

The total phenolics content of MEHA was determined using Folin-Ciocalteu reagent following the method described by Singleton et al. [48]. Briefly, MEHA $(200 \mu \mathrm{L})$ was mixed with $400 \mu \mathrm{L}$ of Folin-Ciocalteu reagent and $1.5 \mathrm{~mL}$ of $20 \%$ sodium carbonate. The mixture was shaken thoroughly followed by addition of distilled water to make a volume up to $10 \mathrm{~mL}$, and then allowed to stand for $2 \mathrm{~h}$. The absorbance was measured at $765 \mathrm{~nm}$ by UV-Spectrophotometer. The concentration of total phenolics content in the extract (10-200 $\mu \mathrm{g} / \mathrm{mL}$ ) was determined using gallic acid standard curve and results were expressed as mg gallic acid equivalent (GAE) per g of extract (mg GAE/g). The test was analyzed and results were articulated as mean \pm SEM.

\subsection{Total Flavonoids Content}

Total flavonoids content was measured following a method described by Kumaran et al. [49] using quercetin as a reference standard. Briefly, $1 \mathrm{~mL}$ of MEHA in methanol $(10 \mathrm{mg} / \mathrm{mL})$ was mixed with $1 \mathrm{~mL}$ aluminum trichloride in methanol $(20 \mathrm{mg} / \mathrm{mL})$ and a drop of acetic acid, and then diluted with methanol to $25 \mathrm{~mL}$. The mixture was allowed to stand for $40 \mathrm{~min}$ followed by measuring the absorbance at $415 \mathrm{~nm}$. Finally, total flavonoid content was determined using quercetin $(12.5-100 \mu \mathrm{g} / \mathrm{mL})$ standard calibration curve. The values were expressed as $\mathrm{mg}$ of quercetin equivalent $(\mathrm{QE})$ per $\mathrm{g}$ of 
extract (mg QE/g). The test was performed for three times and results were expressed as mean \pm SEM.

\subsection{Thrombolytic Activity}

This experiment was done according to the method delineated by Prasad et al. [50]. Briefly, $5 \mathrm{~mL}$ sterile distilled water was added in the commercially available lyophilized streptokinase vial $(1,500,000 \mathrm{IU})$ and mixed uniformly for using it as a stock solution. Appropriate dilution was prepared from the stock solution. Next, $5 \mathrm{~mL}$ of venous blood was drawn from the healthy volunteers $(n=10)$ without having the history of oral contraceptive or oral anticoagulant therapy as well as having normal physiological parameters (blood pressure, heart rate, BMI and body temperature). The collected blood was distributed $(0.5 \mathrm{~mL} /$ tube $)$ to each ten previously weighed sterile micro centrifuge tube and incubated at $37^{\circ} \mathrm{C}$ for $45 \mathrm{~min}$ to form the clot. After clot formation serum was completely removed without dislodged the clot and clot weight was determined from each tube by again measuring the tube weight. Then, $100 \mu \mathrm{L}$ of MEHA $(10 \mathrm{mg} / \mathrm{mL})$ was added to each micro-centrifuge tube containing pre weighed clot. A volume of $100 \mu \mathrm{L}$ streptokinase as a positive control and $100 \mu \mathrm{L}$ distilled water as a negative control were separately added to the marked control tubes. For clot lysis observation, all the tubes were then incubated for $90 \mathrm{~min}$ at $37^{\circ} \mathrm{C}$. After incubation, released fluid was removed and the tubes were weighed again to observe the difference in weight after clot disruption. The percentage of clot lysis was determined by taking the difference in weight before and after clot lysis.

\subsection{In Vivo Neuropharmacological Activity \\ 3.7.1. Experimental Animals}

Five week-old Swiss albino mice weighing 28-32 g were purchased from animal house of Department of Pharmacy, Jahangirnagar University, Savar, Dhaka, Bangladesh. The mice were acclimatized to the new environment for a week before starting of experiment. During experiment period all animals were maintained in a well-ventilated animal house at $25 \pm 2{ }^{\circ} \mathrm{C}$ and relative humidity of $50-60 \%$. Standard food pellets and fresh drinking water were supplied throughout the experimental periods. All mice were kept in cage and maintained with natural $12 \mathrm{~h}$ light and dark cycle. This animal experiment was designed on the basis of the Ethical Principles and Guidelines guided by the Swiss Academy of Medical Sciences and the Swiss Academy of Sciences. The study protocol was permitted by both the Ethical review committee and the P\&D committee of the Department of Pharmacy, International Islamic University Chittagong, Bangladesh under the code Pharm-P\&D61/0818-122.

\subsubsection{Acute Toxicity Study}

The allocated mice were fasted overnight followed by single oral administration of MEHA (500, 1000 and $2000 \mathrm{mg} / \mathrm{kg}$, body weight). The untreated mice were served as negative control. Mice were checked individually for any physical abnormal behavior and symptoms including allergic syndromes like skin rash, itching, swelling, respiratory complexity and mortality for next $72 \mathrm{~h}$. After that, the mice were euthanized by $\mathrm{CO}_{2}$ inhalation and were monitored for respiratory cessation and left in the chamber for $1 \mathrm{~min}$ after the respiration has stopped.

\subsubsection{Anxiolytic Activity \\ Elevated Plus Maze Test}

The test was accomplished based on the method described by Pello et al. [51]. We concurred the method used by Adnan at al. [52]. Briefly, the apparatus which was elevated $40 \mathrm{~cm}$ from the floor containing two open arms $(5 \mathrm{~cm} \times 10 \mathrm{~cm})$ and two closed arms $(5 \mathrm{~cm} \times 10 \mathrm{~cm} \times 15 \mathrm{~cm})$ that were merged together in a central platform $(5 \mathrm{~cm} \times 5 \mathrm{~cm})$ and exposed as plus sign symbol. The mice were distributed randomly into control, standard and treatments groups where each containing 3 mice. Treatment groups mice 
were orally administered 200 and $400 \mathrm{mg} / \mathrm{kg}$ body weight of MEHA, whereas control groups mice received vehicle ( $1 \%$ Tween 80 dissolved in water, $10 \mathrm{~mL} / \mathrm{kg}$ ) orally; and diazepam $(1 \mathrm{mg} / \mathrm{kg}$, intraperitoneally) was administered to the standard groups. After $30 \mathrm{~min}$, each mice was kept in the middle of the platform, facing to closed arms and allowed free movement for $5 \mathrm{~min}$. During experiments, open arms entries and total time spent by mice was recorded.

Hole Board Test

The hole board apparatus was used as delineated by Clark et al. [53]. In this experiment, a grid-pattern containing 16 holes of $3 \mathrm{~cm}$ diameter in a flat platform with an enclosed space $(40 \mathrm{~cm} \times 40 \mathrm{~cm} \times 25 \mathrm{~cm})$ setting up by elevating $25 \mathrm{~cm}$ from the floor was used. The instrument contains a hole in the middle of the two connecting frames. The control (1\% Tween 80, $10 \mathrm{~mL} / \mathrm{kg}$, p.o), standard (diazepam, $1 \mathrm{mg} / \mathrm{kg}$, i.p) and treatment (200 mg/kg and $400 \mathrm{mg} / \mathrm{kg}$, p.o) groups' mice were allowed to have free movement from middle of the board after 30 min of treatment. Total number of head dipping through the holes were counted for 5 min during the exploration by mice.

\subsubsection{Antidepressant Activity}

Tail Suspension Test

The tail suspension method was described by Steru at al. [37]. It is a simple and reliable method for screening of antidepressant agents. After 30 min of administration of control (1\% Tween $80,10 \mathrm{~mL} / \mathrm{kg}$, p.o) standard (imipramine hydrochloride, $10 \mathrm{mg} / \mathrm{kg}$ b.w, i.p) and treatment groups (200 and $400 \mathrm{mg} / \mathrm{kg}$ b.w, p.o), the mice were induced in a depression state (immobility), hanging by end of the tail nearly $1 \mathrm{~cm}$ from tip of the tail using an adhesive tape. Total immobile time was recorded for last 4 min of a total 6 min (initial adjustment time $2 \mathrm{~min}$ ) of hanging.

\section{Forced Swimming Test}

This test was executed as delineated by Porsolt et al. [36]. The experiment was designed to carry out in two session, for example, introductory test was conducted the day before the final experiment for adapting the mice with new environment. A transparent glass tank of $25 \mathrm{~cm} \times 15 \mathrm{~cm} \times 25 \mathrm{~cm}$ filled up to $15 \mathrm{~cm}$ with water of $25 \pm 1{ }^{\circ} \mathrm{C}$ temperature was used for swimming. After $30 \mathrm{~min}$ of treatment, the treated mice of each groups, for instance, treatments (200 and $400 \mathrm{mg} / \mathrm{kg} \mathrm{b.w,} \mathrm{p.o),} \mathrm{standard} \mathrm{(imipramine} \mathrm{hydrochloride,}$ $10 \mathrm{mg} / \mathrm{kg}$ b.w, i.p) and control (1\% Tween $80,10 \mathrm{~mL} / \mathrm{kg}, \mathrm{p} . \mathrm{o})$ was individually placed in the tank for 6 min where initial adjustment time $2 \mathrm{~min}$ and the immobility duration were measured for next $4 \mathrm{~min}$.

\subsection{Protein and Chemical Compounds Studied in This Investigation}

From the depository of PDB, 4 proteins were considered for the purpose of this study; xanthine oxidoreductase (PDB: 2CKJ), tissue plasminogen activator receptor (PDB: $1 \mathrm{~A} 5 \mathrm{H})$, potassium channel receptor (PDB: $4 U U \mathrm{UU}$ ), and human serotonin receptor (PDB: 5I6X). The biomolecules studied in this research are included in the essential oils obtained from the leaves of the H. aromatica. These were; 1,2-dimethylbenzene (CID: 7237), 4-terpineol (CID: 11230), $\alpha$-cadinene (CID: 12306048), $\alpha$-cadinol (CID: 10398656), $\alpha$-pinene (CID: 6654), bullatantriol (CID: 71430886), camphene (CID: 6616), cis-linalool oxide (CID: 6428573), cryptone (CID: 92780), linalyl acetate (CID: 8294), nerol (CID: 643820), oplodiol (CID: 12313756), spatulenol (CID: 92231) and T-cadinol (CID: 160799).

\subsection{In Silico Studies}

\subsubsection{Molecular Docking: Preparation of Ligands}

The 2D SDF format of identified compounds was attained from PubChem database of chemical repository (https:/ / pubchem.ncbi.nlm.nih.gov / (accessed on 1 November 2020)) [54]. LigPrep (bioinformatics tool, part of the Schrödinger-Maestro v 11.1 suite, New 
York, NY, USA) was used to execute ligand-preparation process [55]. The following factors were kept in consideration during this job: chemical structure was setup as project table, the force field: OPLS3, the target pH: $7.0 \pm 2.0$ using Epik 2.2.

\subsubsection{Molecular Docking: Preparation of Proteins/Enzymes}

The receptors proteins were received from the database of Protein Data Bank (PDB) (https:/ / www.rcsb.org/ (accessed on 1 November 2020)). The structures (3D) were taken in PDB format. Pre-processing and minimization step were completed through ProteinPreparation wizard also included in the Schrödinger Maestro v 11.1 suite [55]. The factors that were kept in consideration during this work: the structures optimization $\mathrm{pH}: 7$ and protein minimization done by using OPLS3 force-field. Lastly, the receptor grid selected by using PockDrug which is an online tool for picking the finest binding site.

\subsubsection{Molecular Docking: Glide Standard Precision Docking}

The docking was executed to assume the conceivable mechanism of the regarding compounds along with the comparison against reference drugs with the associated receptors along with several pharmacological activities. The operation was accomplished by the Ligand-Docking tool of the Schrödinger Maestro software (v 11.1) suite [55]. Afterward, the spreadsheets were collected for additional analysis. Discovery Studio was utilized for better understanding the interaction with 3D imaging.

\subsubsection{Prediction of the Pharmacokinetic Parameters (ADME)}

Several pharmacokinetic properties (absorption, distribution, metabolism, excretion) are of concern during the development process of a therapeutic drug. To describe the numerous biochemical properties the following parameters were explored by SwissADME based on the Lipinski's and Veber's Rules [56]: molecular weight (MW), hydrogen bond acceptor (HBA), hydrogen bond donor (HBD), lipophilicity (log P value), number of the rotatable (nRB) and topological polar surface area (TPSA).

\subsubsection{Prediction of Toxicological Properties}

Determination of toxicological properties is the most crucial in case of the advancement of new therapeutic candidate. A bio-informatics tool named AdmetSAR was castoff to assess the toxicological properties of selective compounds [57]. Various parameters such as rat acute toxicity, acute oral toxicity, Ames toxicity, and carcinogenic properties were kept the focus of these tests.

\subsection{Statistical Analysis}

Data were analysed by using one way ANOVA followed by Dunnett's multiple comparison tests. GraphPad Prism version 8 software (GraphPad Software Inc., San Diego, CA, USA) was used and the results expressed as mean \pm standard error of mean (SEM) where $p<0.05$ was considered statistically significant.

\section{Conclusions}

The obtained results support the notion that $H$. aromatica possesses medicinal value for the treatment of thrombotic, anxiety and depressive disorders. The phytochemical assessment for antioxidant, phenol and flavonoid contents reinforce the potential of using this plant as a source of anxiolytic and antidepressant treatments. Moreover, the presence of antioxidant and polyphonic compounds make this plant as important choice for treatment of blood clotting ailments. Altogether, these outcomes strongly corroborate the folklore use and popularity of this plant. Furthermore, in silico studies of bioactive compounds have shown promising binding affinities towards different receptors in a molecular docking exploration. The possible pharmacological activities, safety, toxicological properties of the bioactive compounds establish the use of this plant as a promising therapeutic source. Therefore, $H$. aromatica can be considered as a candidate for the development of new drugs. 
However, comprehensive studies are still needed to isolate and purify novel bioactive leads to reveal the biological activity and mechanism of the observed pharmacological activities.

Author Contributions: M.S.A. and H. designed the experiments, prepared plant extract, performed experiments. M.S.A. drafted the manuscript. S.A.J.S. and M.S.A. performed in silico studies. Y.Q., E.-B.L., B.T.B., K.S. and S.-C.P. revised and improved the manuscript. K.S. and P.S.C. validated and supervised the study. All authors have read and agreed to the published version of the manuscript.

Funding: This research is funded in part by the National Research Foundation of Korea (NRF) through the Ministry of Education (2019R1A2C2006277) and in part by a grant (Z-1543081-2020-22-02) from the Animal and Plant Quarantine Agency, Ministry of Agriculture, Food and Rural Affairs, Republic of Korea. The funders had no role in study design, data collection and interpretation, or the decision to submit the work for publication.

Institutional Review Board Statement: This study was conducted according to the guidelines of the Declaration of Helsinki, and the protocol was permitted by ethical review committee of the Department of Pharmacy, International Islamic University Chittagong, Bangladesh under the code of Pharm-P\&D-61/0818-122 (1 August 2018).

Data Availability Statement: The data presented in this study are available on the request from the corresponding author.

Acknowledgments: This research was supported by the Department of Pharmacy, International Islamic University Chittagong 4318, Bangladesh and Kyungpook National University, Daegu, Republic of Korea.

Conflicts of Interest: The authors declare no conflict of interest.

Sample Availability: Samples of the compounds are not available from the authors.

\begin{tabular}{ll}
\multicolumn{2}{l}{ Abbreviations } \\
PDB & Protein data bank \\
GABA & Gamma amino butyric acid \\
p.o & per oral \\
i.p & intraperitoneal \\
ADME/T & Absorption, distribution, metabolism, excretion and toxicity \\
BMI & Basal metabolic rate \\
ANOVA & Analysis of variance \\
SPSS & Statistical package for social science \\
SEM & Standard error of mean
\end{tabular}

\section{References}

1. Wendelboe, A.M.; Raskob, G.E. Global burden of thrombosis: Epidemiologic aspects. Circ. Res. 2016, 118, 1340-1347. [CrossRef]

2. Kara, S.; Yazici, K.M.; Güleç, C.; Ünsal, I. Mixed anxiety-depressive disorder and major depressive disorder: Comparison of the severity of illness and biological variables. Psychiatry Res. 2000, 94, 59-66. [CrossRef]

3. Hassan, W.; Eduardo Barroso Silva, C.; Mohammadzai, I.U.; Batista Teixeira da Rocha, J.; Landeira-Fernandez, J. Association of oxidative stress to the genesis of anxiety: Implications for possible therapeutic interventions. Curr. Neuropharmacol. 2014, 12, 120-139. [CrossRef]

4. Beckhauser, T.F.; Francis-Oliveira, J.; De Pasquale, R. Reactive oxygen species: Physiological and physiopathological effects on synaptic plasticity: Supplementary issue: Brain plasticity and repair. J. Exp. Neurosci. 2016, 10, S39887. [CrossRef] [PubMed]

5. García-Gutiérrez, M.S.; Navarrete, F.; Gasparyan, A.; Austrich-Olivares, A.; Sala, F.; Manzanares, J. Cannabidiol: A potential new alternative for the treatment of anxiety, depression, and psychotic disorders. Biomolecules 2020, 10, 1575. [CrossRef] [PubMed]

6. Jyoti, M.A.; Barua, N.; Hossain, M.S.; Hoque, M.; Bristy, T.A.; Mahmud, S.; Adnan, M.; Chy, M.; Uddin, N.; Paul, A. Unravelling the biological activities of the Byttneria pilosa leaves using experimental and computational approaches. Molecules 2020, $25,4737$. [CrossRef] [PubMed]

7. Kehie, P.; Pfoze, N.L. Phytochemical and ethnopharmacological overview of endangered Homalomena aromatica Schott: An aromatic medicinal herb of Northeast India. Indian J. Nat. Prod. Resour. 2017, 8, 18-31.

8. Van, T.H.; Nguyen, Q.P.; Tran, G.B.; Huynh, N.T.A. Chemical composition and antibacterial activities of Homalomena vietnamensis bogner \& vd nguyen (Araceae). J. Microbiol. Biotechnol. Food Sci. 2020, 10, 201-204. 
9. Chandana, C.B.; Anindita, T.; Anindhya, S.D.; Acheenta, G.B.; Debesh, C.P. Ulcer protective activity of ethanolic extract of Homalomena aromatica Schott. (Araceae) Root. Adv. Tech. Biol. Med. 2014, 2, 117.

10. Dutta, B.; Lahkar, M.; Augustine, B.B.; Lihite, R.J. Hepatoprotective activity of Tamarind indica and Homalomena aromatica in rats. Carbon N. Y. 2013, 100, 2.

11. Policegoudra, R.S.; Goswami, S.; Aradhya, S.M.; Chatterjee, S.; Datta, S.; Sivaswamy, R.; Chattopadhyay, P.; Singh, L. Bioactive constituents of Homalomena aromatica essential oil and its antifungal activity against dermatophytes and yeasts. J. Mycol. Med. 2012, 22, 83-87. [CrossRef]

12. Roy, S.J.; Baruah, P.S.; Lahkar, L.; Gurung, L.; Saikia, D.; Tanti, B. Phytochemical analysis and antioxidant activities of Homalomena aromatic Schott. J. Pharmacogn. Phytochem. 2019, 8, 1379-1385.

13. Michel, J.; Abd Rani, N.Z.; Husain, K. A review on the potential use of medicinal plants from Asteraceae and Lamiaceae plant family in cardiovascular diseases. Front. Pharmacol. 2020, 11, 852. [CrossRef] [PubMed]

14. Ren, G.; Zhong, Y.; Ke, G.; Liu, X.; Li, H.; Li, X.; Zheng, Q.; Yang, M. The mechanism of compound anshen essential oil in the treatment of insomnia was examined by network pharmacology. Evid. Based Complement. Altern. Med. 2019, $2019,9241403$. [CrossRef]

15. Wolffenbüttel, A.N.; Zamboni, A.; Becker, G.; Dos Santos, M.K.; Borille, B.T.; de Cássia Mariotti, K.; Fagundes, A.C.; de Oliveira Salomón, J.L.; Coelho, V.R.; Ruiz, L.V. Citrus essential oils inhalation by mice: Behavioral testing, GCMS plasma analysis, corticosterone, and melatonin levels evaluation. Phyther. Res. 2018, 32, 160-169. [CrossRef]

16. Koehn, F.E.; Carter, G.T. The evolving role of natural products in drug discovery. Nat. Rev. Drug Discov. 2005, 4, 206-220. [CrossRef]

17. Bruhn, J.G.; Bohlin, L. Molecular pharmacognosy: An explanatory model. Drug Discov. Today 1997, 2, 243-246. [CrossRef]

18. Berton, O.; Nestler, E.J. New approaches to antidepressant drug discovery: Beyond monoamines. Nat. Rev. Neurosci. 2006, 7, 137-151. [CrossRef]

19. Chen, C.; Yang, F.-Q.; Zhang, Q.; Wang, F.-Q.; Hu, Y.-J.; Xia, Z.-N. Natural products for antithrombosis. Evid. Based Complement. Altern. Med. 2015, 2015, 876426. [CrossRef] [PubMed]

20. Ngan, A.; Conduit, R. A double-blind, placebo-controlled investigation of the effects of Passiflora incarnata (passionflower) herbal tea on subjective sleep quality. Phytother. Res. 2011, 25, 1153-1159. [CrossRef] [PubMed]

21. Agha-Hosseini, M.; Kashani, L.; Aleyaseen, A.; Ghoreishi, A.; Rahmanpour, H.; Zarrinara, A.R.; Akhondzadeh, S. Crocus sativus L. (saffron) in the treatment of premenstrual syndrome: A double-blind, randomised and placebo-controlled trial. BJOG 2008, 115, 515-519. [CrossRef]

22. Ramjan, A.; Hossain, M.; Runa, J.F.; Md, H.; Mahmodul, I. Evaluation of thrombolytic potential of three medicinal plants available in Bangladesh, as a potent source of thrombolytic compounds. Avicenna J. Phytomed. 2014, 4, 430-436.

23. Violi, F.; Pignatelli, P. Platelet oxidative stress and thrombosis. Thromb. Res. 2012, 129, 378-381. [CrossRef]

24. Loscalzo, J. Oxidant stress: A key determinant of atherothrombosis. Biochem. Soc. Trans. 2003, 31, 1059-1061. [CrossRef] [PubMed]

25. Rammal, H.; Bouayed, J.; Younos, C.; Soulimani, R. Evidence that oxidative stress is linked to anxiety-related behaviour in mice. Brain Behav. Immun. 2008, 22, 1156-1159. [CrossRef]

26. Choe, E.; Min, D.B. Mechanisms of antioxidants in the oxidation of foods. Compr. Rev. Food Sci. Food Saf. 2009, 8, 345-358. [CrossRef]

27. Pandey, K.B.; Rizvi, S.I. Plant polyphenols as dietary antioxidants in human health and disease. Oxid. Med. Cell. Longev. 2009, 2, 270-278. [CrossRef]

28. Wang, X.; Chen, Y.; Wang, Q.; Sun, L.; Li, G.; Zhang, C.; Huang, J.; Chen, L.; Zhai, H. Support for natural small-molecule phenols as anxiolytics. Molecules 2017, 22, 2138. [CrossRef]

29. Hritcu, L.; Ionita, R.; Postu, P.A.; Gupta, G.K.; Turkez, H.; Lima, T.C.; Carvalho, C.U.S.; de Sousa, D.P. Antidepressant flavonoids and their relationship with oxidative stress. Oxid. Med. Cell. Longev. 2017, 2017, 5762172. [CrossRef] [PubMed]

30. Habauzit, V.; Morand, C. Evidence for a protective effect of polyphenols-containing foods on cardiovascular health: An update for clinicians. Ther. Adv. Chronic Dis. 2012, 3, 87-106. [CrossRef] [PubMed]

31. Opie, L.H.; Lecour, S. The red wine hypothesis: From concepts to protective signalling molecules. Eur. Heart J. 2007, 28 , 1683-1693. [CrossRef]

32. Joshipura, K.J.; Ascherio, A.; Manson, J.E.; Stampfer, M.J.; Rimm, E.B.; Speizer, F.E.; Hennekens, C.H.; Spiegelman, D.; Willett, W.C. Fruit and vegetable intake in relation to risk of ischemic stroke. JAMA 1999, 282, 1233-1239. [CrossRef] [PubMed]

33. Liu, S.; Manson, J.E.; Lee, I.M.; Cole, S.R.; Hennekens, C.H.; Willett, W.C.; Buring, J.E. Fruit and vegetable intake and risk of cardiovascular disease: The Women's Health Study. Am. J. Clin. Nutr. 2000, 72, 922-928. [CrossRef]

34. Rathee, P.; Chaudhary, H.; Rathee, S.; Rathee, D.; Kumar, V.; Kohli, K. Mechanism of action of flavonoids as anti-inflammatory agents: A review. Inflamm. Allergy Drug Targets 2009, 8, 229-235. [CrossRef] [PubMed]

35. Nic Dhonnchadha, B.A.; Bourin, M.; Hascoët, M. Anxiolytic-Like effects of 5-HT2 ligands on three mouse models of anxiety. Behav. Brain Res. 2003, 140, 203-214. [CrossRef]

36. Porsolt, R.D.; Bertin, A.; Jalfre, M. Behavioral despair in mice: A primary screening test for antidepressants. Arch. Int. Pharmacodyn. Ther. 1977, 229, 327.

37. Steru, L.; Chermat, R.; Thierry, B.; Simon, P. The tail suspension test: A new method for screening antidepressants in mice. Psychopharmacology 1985, 85, 367-370. [CrossRef] 
38. Tallman, J.F.; Cassella, J.; Kehne, J.; Corpora, N. Mechanism of Action of Anxiolytics; American College of Neuropsychopharmacology: Brentwood, TN, USA, 2002.

39. Nestler, E.J.; Barrot, M.; DiLeone, R.J.; Eisch, A.J.; Gold, S.J.; Monteggia, L.M. Neurobiology of depression. Neuron 2002, $34,13-25$. [CrossRef]

40. Luscher, B.; Shen, Q.; Sahir, N. The GABAergic deficit hypothesis of major depressive disorder. Mol. Psychiatry 2011, 16, 383-406. [CrossRef]

41. Arborelius, L.; Owens, M.J.; Plotsky, P.M.; Nemeroff, C. The role of corticotropin-releasing factor in depression and anxiety disorders. J. Endocrinol. 1999, 160, 1-12. [CrossRef]

42. Bordia, A.K.; Sanadhya, S.K.; Rathore, A.S.; Bhu, N. Essential oil of garlic on blood lipids and fibrinolytic activity in patients of coronary artery disease. Part I. J. Assoc. Physicians India 1978, 26, 327-331. [PubMed]

43. Setzer, W.N. Essential oils and anxiolytic aromatherapy. Nat. Prod. Commun. 2009, 4. [CrossRef]

44. De Sousa, D.P.; Silva, R.H.N.; da Silva, E.F.; Gavioli, E.C. Essential oils and their constituents: An alternative source for novel antidepressants. Molecules 2017, 22, 1290. [CrossRef]

45. Veber, D.F.; Johnson, S.R.; Cheng, H.-Y.; Smith, B.R.; Ward, K.W.; Kopple, K.D. Molecular properties that influence the oral bioavailability of drug candidates. J. Med. Chem. 2002, 45, 2615-2623. [CrossRef]

46. Braca, A.; De Tommasi, N.; Di Bari, L.; Pizza, C.; Politi, M.; Morelli, I. Antioxidant principles from Bauhinia tarapotensis. J. Nat. Prod. 2001, 64, 892-895. [CrossRef] [PubMed]

47. Adnan, M.; Chy, M.; Uddin, N.; Kamal, A.T.M.; Chowdhury, K.A.A.; Rahman, M.; Reza, A.S.M.; Moniruzzaman, M.; Rony, S.R.; Nasrin, M. Intervention in neuropsychiatric disorders by suppressing inflammatory and oxidative stress signal and exploration of in silico studies for potential lead compounds from Holigarna caustica (Dennst.) Oken leaves. Biomolecules 2020, 10, 561. [CrossRef]

48. Singleton, V.L.; Orthofer, R.; Lamuela-Raventós, R.M. Analysis of total phenols and other oxidation substrates and antioxidants by means of folin-ciocalteu reagent. Methods Enzymol. 1999, 299, 152-178.

49. Kumaran, A.; Karunakaran, R.J. In vitro antioxidant activities of methanol extracts of five Phyllanthus species from India. LWT Food Sci. Technol. 2007, 40, 344-352. [CrossRef]

50. Prasad, S.; Kashyap, R.S.; Deopujari, J.Y.; Purohit, H.J.; Taori, G.M.; Daginawala, H.F. Development of an in vitro model to study clot lysis activity of thrombolytic drugs. Thromb. J. 2006, 4, 14. [CrossRef]

51. Pellow, S.; File, S.E. Anxiolytic and anxiogenic drug effects on exploratory activity in an elevated plus-maze: A novel test of anxiety in the rat. Pharmacol. Biochem. Behav. 1986, 24, 525-529. [CrossRef]

52. Adnan, M.; Chy, M.; Uddin, N.; Kamal, A.T.M.; Chowdhury, M.; Islam, M.; Hossain, M.; Tareq, A.M.; Bhuiyan, M.; Hossain, I. Unveiling pharmacological responses and potential targets insights of identified bioactive constituents of Cuscuta reflexa Roxb. leaves through in vivo and in silico approaches. Pharmaceuticals 2020, 13, 50. [CrossRef]

53. Clark, G.; Koester, A.G.; Pearson, D.W. Exploratory behavior in chronic disulfoton poisoning in mice. Psychopharmacologia 1971, 20, 169-171. [CrossRef]

54. Kim, S.; Thiessen, P.A.; Bolton, E.E.; Chen, J.; Fu, G.; Gindulyte, A.; Han, L.; He, J.; He, S.; Shoemaker, B.A. PubChem substance and compound databases. Nucleic Acids Res. 2016, 44, D1202-D1213. [CrossRef] [PubMed]

55. Bhachoo, J.; Beuming, T. Investigating protein-peptide interactions using the Schrödinger computational suite. In Modeling Peptide-Protein Interactions; Springer: Cham, Switzerland, 2017; pp. 235-254.

56. Daina, A.; Michielin, O.; Zoete, V. SwissADME: A free web tool to evaluate pharmacokinetics, drug-likeness and medicinal chemistry friendliness of small molecules. Sci. Rep. 2017, 7, 42717. [CrossRef] [PubMed]

57. Cheng, F.; Li, W.; Zhou, Y.; Shen, J.; Wu, Z.; Liu, G.; Lee, P.W.; Tang, Y. AdmetSAR: A comprehensive source and free tool for assessment of chemical ADMET properties. J. Chem. Inf. Model. 2012, 52, 3099-3105. [CrossRef] [PubMed] 